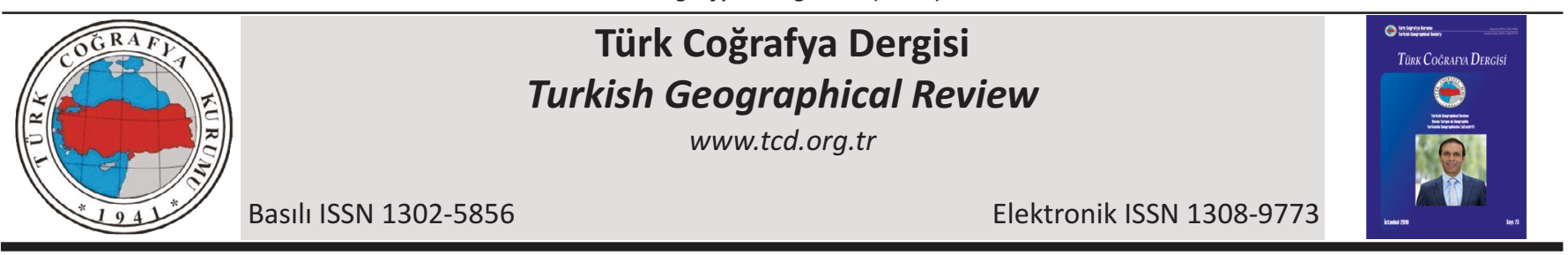

\title{
İstanbul ili, Bahçelievler ilçesinde park ve yeşil alan kullanımı
}

\section{Park and green area use in İstanbul province, Bahçelievler district}

\author{
Rüştü llgar*a (D) Yücel Şeran ${ }^{b}$ (iD \\ ${ }^{a}$ Çanakkale Onsekiz Mart Üniversitesi, Eğitim Fakültesi, Cografya Egitim Anabilim Dalı, Çanakkale. \\ ${ }^{b}$ Coğrafya Öğretmeni, Inönü Mesleki ve Teknik Anadolu Lisesi, Istanbul.
}

\section{BILGI / INFO}

Geliş/Received: 23.03.2019

Kabul/Accepted: 29.06.2019

Anahtar Kelimeler:

Bahçelievler

Kentsel yeşil alan

Park

Rekreasyon

\section{Keywords:}

Bahçelievler

Urban green area

Park

Recreation

*Sorumlu yazar/Corresponding author: (R. Ilgar) ilgar@comu.edu.tr

DOI: $10.17211 /$ tcd. 543667

\section{Atif/Citation:}

Şenkul, Ç. ve Doğan, M. (2018). Fosil ve güncel polen analizleri ışı̆̆ında Mucur Obruk Gölü çevresinin Paloevejetasyon değişimleri. Türk Coğrafya Dergisi (73), 7-16. DOI:10.17211/tcd.543667.

\begin{abstract}
ÖZ / ABSTRACT
Bu çalışmanın amacı İstanbul ili Bahçelievler ilçesindeki park ve yeşil alanların nitelik ve nicelik yönünden, kullanıcı memnuniyetine dayalı anket çalışmasını kullanarak, tarama modeli, mülakat ve gözlem yöntemleriyle değerlendirmelerde bulunmaktır. Ayrıca dünyanın farklı bölgelerindeki ve ülkemizdeki şehirler ile Bahçelievler ilçesindeki kişi başına düşen yeşil alan miktarlarını karşılaştırıp çıkarımlarda bulunulmuştur. Örneklemleri çalışma alanı içerisinden seçilen 15 adet park ve anket sırasında parkta bulunan rastgele örneklem yöntemi ile seçilmiş 473 kişi oluşturmaktadır. Anketin örnekleme uygulanması sonucunda bulunan veriler IBM SPSS 23.0 (Statistical Package for Social Sciences) programına girilerek değerlendirmeye alınmıştır. Katılımcıların park ve yeşil alan kullanımını ölçmeye yönelik betimsel istatistikler sunulmuş, devamında ki-kare testi ile demografik özelliklere göre park kullanım alışkanlıkları arasındaki farklııklar belirlenmiştir. Parklardan duyulan genel memnuniyet düzeyi ve demografik özelliklere yönelik çarpık dağılım gözetilerek uygun olan Kruskal Wallis $\mathrm{H}$ testi ve Mann- Whitney $\mathrm{U}$ testleri ile değişiklikler irdelenmiştir. Çalışmanın sonuç kısmında kentlerin vazgeçilmez bir parçası olan rekreasyonel alanların nitelik ve nicelik yönünden değerlendirmesi yapılarak önemi ortaya konulmuş ve bazı öneriler getirilmiştir.
\end{abstract}

The purpose of this praxis is to appraisal parks and green areas in Bahçelievler district of Istanbul province in terms of quality and quantity by survey model, interview and observation methods using survey study based on user satisfaction. Furthermore, the amount of green land per capita in Bahçelievler district is compared to the amount of green land per capita in other cities as different parts of the world and some deductions have been made in our country. Data gathered as a result of conducting the survey to 473 samples has been analyzed in 15 parks using by IBM SPSS 23.0 (Statistical Package for Social Sciences) software. Descriptive statistics used for measuring park and green area usage of participants have been presented and differences in park usage habits have been determined depending on demographic characteristics by chi-square test. The differences have been studied through using appropriate Kruskal Wallis $H$ test and Mann-Whitney $U$ tests by observing the level of overall delight concerning parks and skewed distribution depending on demographic characteristics. As a result of the study, the importance of recreational areas, which are the essential areas in cities, have been revealed by their evaluation concerning their quantity and quality and it comes up with some suggestions.

\section{Giriş}

Bahçelievler ilçesi yaklaşık olarak $28^{\circ} 49^{\prime} 0^{\prime \prime}-28^{\circ} 53^{\prime} 0^{\prime \prime}$ doğu meridyenleri ile $40^{\circ} 59^{\prime} 30^{\prime \prime}-41^{\circ} 1^{\prime} 30^{\prime \prime}$ kuzey paralelleri arasında bulunmaktadır. Bahçelievler ilçesi İstanbul'un Avrupa kesiminde E5 kara yolunun kuzeyinde bulunmakta olup güneyinde Bakırköy, batısında Küçükçekmece, kuzeyinde Bağcılar ve doğusunda Güngören ilçeleri bulunmaktadır.

16,7 km² yüz ölçüme sahip Bahçelievler ilçesi Cumhuriyet, Çobançeşme, Fevziçakmak, Hürriyet, Kocasinan, Siyavuşpaşa, Soğanlı, Şirinevler, Yenibosna, Zafer ve Bahçelievler olmak üzere toplamda 11 mahalleden oluşmaktadır.

\subsection{Tarihi süreç}

Bahçelievler ilçesi ve çevresi, “Bizans imparatorluğu ve Osmanlı döneminde İstanbul'un ve bölgenin tarımsal ihtiyacını karşılayan Hepdemon diye bahsedilen bir bölgedir. Bizans döneminde Rumeli'den gelen kervan ve asker konvoylarının Constantinapolis'e geçiş güzergâhı olduğu için imparator sarayları, kiliseler ve konutlar inşa edilmiştir. Ancak bölgede tarihi eser bakımından günümüze hemen hemen hiçbir şey kalmamıştır. İstanbul'u çevreleyen surların yapımında bu alanda yer alan taş ocaklarından yararlanıldığı bilinmektedir" (Bahçelievler Belediyesi Faaliyet Raporu, 2011). Cumhuriyet döneminde Avrupa ile ekonomik ilişkiler gelişince, demir yollarının ihtiyacı karşıla- 
yamaması nedeniyle kara yoluna öncelik verilmiş ve Bahçelievler'in kuzeyinden geçen Londra Asfaltt yapılmıştır. Daha sonra bu yol da yetersiz kalmış ve Bahçelievler'in güneyine yeni E5 kara yolu yapılmıştır. Bu kara yolu çevresine de çok sayıda fabrikanın kurulmasıyla kent plansız bir şekilde büyümeye başlamıştır (Bahçelievler Kaymakamlı̆̆ı, Erişim tarihi: 23 Aralık 2017, http://www.bahcelievler.gov.tr/bahcelievler-ilcesi).

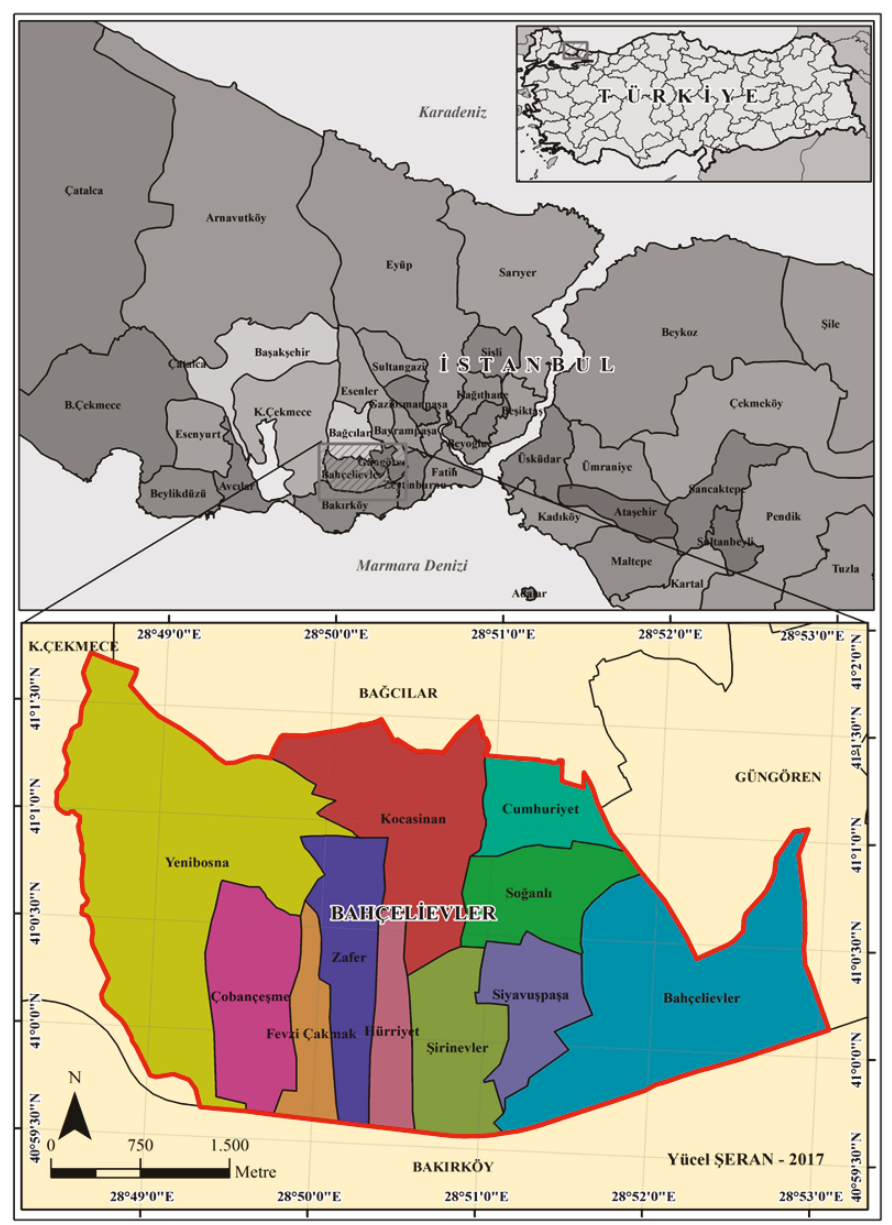

Şekil 1. Bahçelievler ilçesi lokasyon haritası.

Figure 1. Location map of Bahçelievler district.

Bahçelievler, 1969 yılına kadar bir köy, 1984 yılına kadar ise bir belde statüsündedir. 1984 yılında 3030 sayılı yasa ile de Bakırköy İlçe Belediyesi'ne bağlanmıştır. Bahçelievler, 25 Ağustos 1992 tarihinde 3806 sayılı yasa ile Bakırköy ilçesinden ayrılarak bir ilçe olmuştur (Bahçelievler Belediyesi 2015-2019 Stratejik Planı, 2014).

\subsection{Coğrafi yapı}

Jeoloji ve jeomorfoloji: Bahçelievler ilçesinin yükseltisi en fazla olan yeri $90 \mathrm{~m}$, en az olan yeri ise 8-10 m olan vadi ve tepeler üzerinde kurulmuştur. İlçenin büyük bir bölümünün eğimi \% 5 'in altında düz veya düze yakın alanlardan oluştuğu görülmektedir. "Bahçelievler çevresi asıl olarak Eosen ve Miyosen dönemi çökelleri ile kaplıdır. Çalışma alanının kuzeyinden kuzeybatt-güneydoğu doğrultusunda uzanan doruk boyunca, paleozoik temel kayaçları yüzeyde görülmektedir. Alan içerisinde en yaşlı birimi Miyosen yaşlı tabandaki Çukurçeşme formasyonu oluşturmaktadır. Bunun üzerinde ise, Güngören, Bakırköy formasyonları yer alır. Dere yataklarında vadi genişli- ğince Kuvaterner yaşlı alüvyal çökeller bulunmaktadır" (Bahçelievler Belediyesi 2015-2019 Stratejik Planı, 2014).

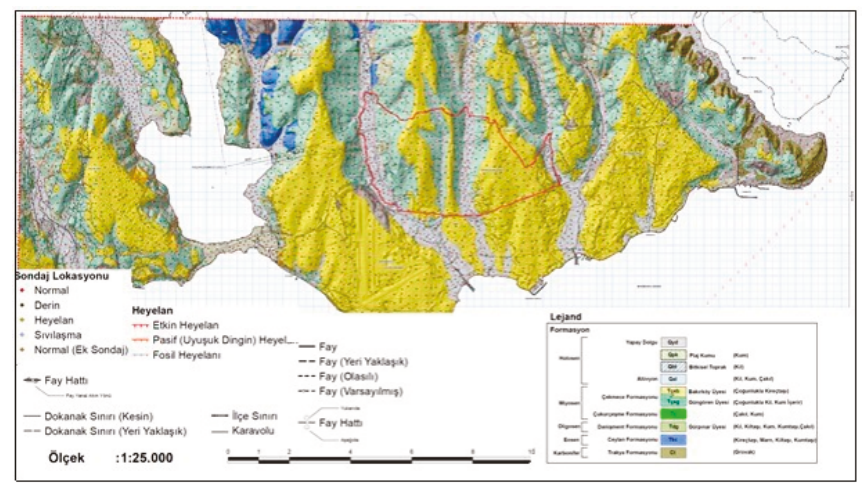

Şekil 2. Bahçelievler ilçesi ve çevresi jeoloji haritası.

Figure 2. Geological map of Bahçelievler and its surroundings.

(http://ibb.gov.tr/sites/akom/Documents/bilimsel_teknik.html, IBB-AKOM, 2018).

Hidrolojik yapı: Bahçelievler ilçesindeki akarsu havzaları yeryüzü şekillerine bağıı olarak kuzeyden güneye doğru akışa sahip derelerden oluşmaktadır. Bu dereler Ayamama (Halkalı), Kocasinan ve Çırpıcı dereleridir. Halkalı Deresi'nin hidrolojik ağı ortalama $30 \mathrm{~km}^{2}$, Çırpıcı Deresi'nin ise $20 \mathrm{~km}^{2}$ 'dir. Bahçelievler'de sürekli akışa sahip akarsu bulunmamakla birlikte yağışlı dönemde yani kış aylarında kısmi akış görülmektedir. Adı geçen derelerdeki akan sular daha ziyade kanalizasyon ve sanayi tesislerinden gelen girdiler kaynaklıdır. Belirtilen üç dere yatağı da ıslah edilmiştir.

Yer altı suyunun yapısı açısından incelendiğinde Trakya formasyonu bölgenin temelini oluşturmakla birlikte genel olarak geçirimsiz bir yapıya sahip olduğu görülür. Yapılan bazı sondajlarda kırık ve çatlaklı kesimlerden günde $15-40 \mathrm{~m}^{3}$ arasında çok az su alınabilmiştir (Bahçelievler Belediyesi 20152019 Stratejik Planı, 2014).

İklim: Bahçelievler ilçesinin iklim özelliklerini ortaya koymak için Florya Meteoroloji ve Gözlem Ölçüm İstasyonu'nun 19602015 yılları arasındaki yaklaşık 56 yıllık ölçüm verileri kullanımıştır. Yıllık ortalama sıcaklık $14.3{ }^{\circ} \mathrm{C}$, ortalama en yüksek sıcaklık $28.6^{\circ} \mathrm{C}$ ile Temmuz ve Ağustos, ortalama en düşük sıcaklık ise $3.2^{\circ} \mathrm{C}$ ile Şubat ayıdır. Genel olarak yağışlar Ekim ile Nisan ayları arasında yoğunlaşmaktadır. Bu dönem aynı zamanda ortalama yağış miktarının üzerinde yağış değerlerine sahiptir. Nisan ayından sonra yağış miktarında ciddi düşüşler yaşanarak kurak bir zaman dilimine girilmektedir. Toplam yıllık yağışın yaklaşık \% 90'ı Kasım- Nisan arası dönemde, \% 10'u ise kurak dönemde gerçekleşmektedir. Yıllık ortalama toplam yağış miktarı 645.8 mm'dir. Ortalama en yüksek yağış 99.9 mm ile Aralık ayında ölçülmüştür (Meteoroloji Genel Müdürlüğü, 2017)

Bitki Örtüsü: İstanbul ilinin doğal bitki örtüsünün maki ve denizsel kıyı bitkilerinden oluştuğu, yer yer de ormanların bulunduğu görülmektedir. "Bahçelievler'de kentleşmenin bu derece entansif yapıya erişmediği yıllarda ilçenin bağlık, ağaçlık, fidanlıklardan oluştuğu kayıtlarda değinilmektedir. Bahçelievler sınırları içerisinde yer alan maki türlerinden mersin (Myrtus communis), kocayemiş (Arbutus unedo), sandal (Arbutus andrachne), defne (Laurus nobilis), zeytin (Olea oleaster), funda 
(Erica arborea), tespih (Styrax ssp.), akçakesme (Phillyrea lotifolia), kermez meşesi (Quercus coccifera), erguvan (Cercis siliquastrum), sakız (Pistacia terebinthus), katran ardıcı (Juniperus oxycedrus), laden (Cistus salviifolius), kattrtirnağı (Spartium junceum) daha çok dere kenarlarında ve mezarlık alanlarında bulunmaktadır" (Bahçelievler Belediyesi 2015-2019 Stratejik Planı, 2014).

\section{Yöntem}

\subsection{Araştırmanın Tasarımı}

Bu çalışmada veri toplama kaynağı olarak dört yol kullanılmıştır. Öncelikle kaynak taraması (survey modeli) yapılmıştır. İkinci olarak arazi çalışması yapılarak araştırma alanına yönelik incelemelerde bulunulmuş ve arazi fotoğraflanmıştır. Üçüncü olarak araştırma alanındaki kişilere yönelik anket çalışması yapılmıştır. Dördüncü olarak ise anket yapılan kişilerle aynı zamanda mülakat da yapılmıştır.

Araştırma nitel bir yapıya sahiptir. Veri toplama kaynaklarından bir diğeri ise mülakattır. "Mülakat, görüş, tutum ve davranışlarını ortaya çıkarmak üzere iki kişi arasındaki (mülakatçı ve kaynak kişi) serbest bilgi değişimine denir" (Balcı, 2007:159). Araşttrmada elde edilen 473 örneklemden sağlanan veriler IBM SPSS 23.0 (Statistical Package for Social Sciences) versiyonu ile değerlendirmeye alınmıştır.

\section{2. Önceki Çalışmalar}

Daha önce yapılmış benzer içerikli çalışmalarda İstanbul-Üsküdar ( Aksoy 2004), İstanbul-Fatih (Aksoy ve Akpınar 2011), İstanbul-Kadıköy'de (Korgavuş ve Ersoy 2015) çalışmalar yürütülmüştür. Ayrıca Aydın (Eşbah,2006), Isparta (Gül ve Küçük 2001), Antalya (Manavoğlu ve Ortaçeşme 2015), Denizli (Yavuzçehre ve Torlak 2006), Burdur (Yenice, 2012), Kars (Yılmaz ve diğ 2013), Kahramanmaraş (Doygun ve İlter 2007) ve Çanakkale (Ayaşlıgil, 1998) illerinde de çalışmalar yapılmıştır. Her il için yeşil alan ve park sıkıntısına değinilmiştir.

\subsection{Araştrrmada Evren ve Örneklem}

Evren, "araştırma sonuçlarının genellenmek istendiği elemanlar bütünüdür. Örneklem ise belli bir evrenden, belli kurallara göre seçilmiş ve seçildiği evreni temsil yeterliği kabul edilen küçük kümedir" (Karasar, 2015:109-110). Bu çalışmanın evrenini İstanbul ili Bahçelievler ilçesinde yer alan park alanları oluşturmaktadır. Bahçelievler İlçesi Park ve Bahçeler Müdürlüğü’nden alınan bilgilere göre toplam 106 adet park bulunmaktadır. Anketin örneklemini ise çalışma alanı içerisinden seçilen 15 adet park ve anket sırasında parkta bulunan rastgele örneklem yöntemi ile belirlenmiş 473 kişiden oluşmaktadır.

\section{Bulgular}

\section{1. Çalışmanın Nitel Bulguları}

Bahçelievler ilçesinde park alanlarının yetersiz olması önemli bir sorundur. İlçe nüfusu diğer komşu ilçeler gibi sürekli olarak nüfus artışına maruz kalmış, özellikle 1960 'Iı yıllardan itibaren bu artış daha da belirginleşmiştir. 1960 yılında 8500 olan Bah-

Tablo 1. Bahçelievler örneklem çalışmalarına dahil olan unsurlar. Table 1. The elements of included in Bahçelievler sample studies.

\begin{tabular}{|ll|}
\hline $\begin{array}{l}\text { EVREN } \\
\text { İstanbul İli Bahçelievler Belediyesi Sınırları İçerisinde Bulunan Park (106 adet), }\end{array}$ \\
\hline ÖRNEKLEME ALINAN PARKLAR VE ANKET SAYILARI (473 kiși) \\
Park adı & Anket sayısı \\
\hline Milli Egemenlik Parkı & 42 \\
Orhan Gazi Parkı & 30 \\
Şelale (Sağlıkı Yaşam) Parkı & 30 \\
Zübeyde Hanım Parkı & 30 \\
Siyavușpaşa Parkı & 30 \\
Doğan Koloğlu Parkı & 31 \\
Șehir Korusu & 33 \\
Yeni Șehir Korusu & 31 \\
Yıldırım Beyazıt Parkı & 34 \\
Aliya İzzet Begoviç Parkı & 30 \\
Kuleli Parkı & 32 \\
Cumhuriyet Parkı & 30 \\
Pașa Sokak Parkı & 30 \\
Sezer Gezer Sokak Parkı & 30 \\
Șehit İbrahim Koparır Parkı & 30 \\
\hline
\end{tabular}

çelievler nüfusu, 1970 yılında \% 572 artişla 51.159’a ulaşmıştır. 1980 yılı verilerine göre ilçe nüfusu 171.040 iken 1990 yılında bu sayı \% 99'luk bir artişla 340.419'a, 2000 yılında ise bu rakam $\%$ 40,60'lık bir artş̧la 478.623'e ulaşmıştır. ADNKS verilerine göre 2007 yılında 571.711'e, 2016 yılında ise 598.097'e yükselmiştir. Veriler incelendiğinde 2013-2016 yılları arasında nüfus artışının durakladığını hatta bir miktar gerilediğini söylemek mümkündür. 2013 yılında 602.931 ile en yüksek seviyeye ulaşan ilçe nüfusu, 2016 yılında 598.097'ye gerilemiştir. Bahçelievler ilçesinin 2016 yılında aritmetik nüfus yoğunluğu ise km²'ye 35.814 kişidir. Bahçelievler nüfusunun \% 99'u iç göçe bağlı olarak artmıştır. İlçe, Türkiye'nin hemen her şehrinden göç almıştir. Göç ile gelenleri geliş yerlerine göre değerlendirecek olursak, ilk sırayı \% 30'luk pay ile Karadeniz Bölgesi'nden gelenler oluşturmaktadır. Bu bölgeyi Doğu Anadolu Bölgesi'nden gelenler \% 20 ile pay ile izler, \% 18'lik payla İç Anadolu Bölgesi gelmektedir (Bahçelievler Belediyesi Faaliyet Raporu, 2011).

Tablo 2. Bahçelievler ilçesi yıllara göre nüfus tablosu. Table 2. Bahçelievler district population table by years.

\begin{tabular}{|c|c|c|c|}
\hline Yillar & Kadın & Erkek & Toplam \\
\hline $1935^{*}$ & - & - & 523 \\
\hline $1940^{*}$ & - & - & 542 \\
\hline $1945^{*}$ & - & - & 601 \\
\hline $1950^{*}$ & - & - & 812 \\
\hline $1955^{*}$ & - & - & 1322 \\
\hline 1960 ** & - & - & 8.500 \\
\hline $1965^{*}$ & - & - & 20.881 \\
\hline $1970^{* *}$ & - & - & 51.159 \\
\hline $1975^{*}$ & - & - & 102.533 \\
\hline 1980 ** & - & - & 171.040 \\
\hline $1985^{*}$ & - & - & 237.691 \\
\hline $1990^{* *}$ & - & - & 340.419 \\
\hline $1997^{*}$ & - & - & 442.877 \\
\hline $2000^{* * *}$ & 239.990 & 238.633 & 478.623 \\
\hline $2007^{* * *}$ & 287.906 & 283.805 & 571.711 \\
\hline $2010^{* * *}$ & 294.794 & 295.263 & 590.057 \\
\hline $2013^{* * *}$ & 299.850 & 303.081 & 602.931 \\
\hline $2015^{* * *}$ & 299.349 & 302.691 & 602.040 \\
\hline $2016^{* * *}$ & 297.392 & 300.705 & 598.097 \\
\hline
\end{tabular}


Bahçelievler'in 598 bin nüfuslu 11 mahalleden oluşan bir ilçedir. İlçenin en düşük nüfuslu mahallesi toplam nüfusun \% 4,41'ini barındıran Fevzi Çakmak Mahallesi olup, en fazla nüfusa sahip mahallesi ise \% 14,31 ile Zafer Mahallesi'dir.

Tablo 3. Mahallelere göre Bahçelievler nüfusu (2016).

Table 3. The population of Bahçelievler by districts (2016).

\begin{tabular}{llll}
\hline $\mathbf{N o}$ & Mahalle & Nüfus & Yüzde (\%) \\
\hline $\mathbf{1}$ & Yenibosna Merkez Mahallesi & 34522 & 5,77 \\
\hline $\mathbf{2}$ & Bahçelievler Mahallesi & 62718 & 10,48 \\
\hline $\mathbf{3}$ & Kocasinan Merkez Mahallesi & 72199 & 12,07 \\
\hline $\mathbf{4}$ & Şirinevler Mahallesi & 56884 & 9,51 \\
\hline $\mathbf{5}$ & Cumhuriyet Mahallesi & 41893 & 7,00 \\
\hline $\mathbf{6}$ & Çobançeşme Mahallesi & 33378 & 5,58 \\
\hline $\mathbf{7}$ & Fevzi Çakmak Mahallesi & 26434 & 4,41 \\
\hline $\mathbf{8}$ & Zafer Mahallesi & 85612 & 14,31 \\
\hline $\mathbf{9}$ & Siyavuşpaşa Mahallesi & $\mathbf{6 6 1 1 7}$ & 11,05 \\
\hline $\mathbf{1 0}$ & Hürriyet Mahallesi & 46755 & 7,81 \\
\hline $\mathbf{1 1}$ & Soğanlı Mahallesi & 71585 & 11,96 \\
\hline & Toplam & $\mathbf{5 9 8 , 0 9 7}$ & $\mathbf{1 0 0 , 0 0}$ \\
\hline
\end{tabular}

“3194 sayılı İmar Kanunu’nun 02.09.1999 tarih ve 23804 sayılı Resmi Gazete'de yayımlanan “imar Planı Yapılması ve Değişikliklerine Ait Esaslara Dair Yönetmelik" hükümlerine göre kentsel alanlarda kişi başına düşen yeşil alan miktarı en az $10 \mathrm{~m}^{2}$, belediye ve mücavir alan sınırları dışında ise kişi başına yeşil alan miktarı en az $14 \mathrm{~m}^{2}$ olarak belirlenmiştir" (Yenice, 2012). Oysa artan nüfusa oranla park sayısındaki artı̧̧ oldukça yetersiz kalmıştır. Bahçelievler ilçesinin toplam \% 7.79'unu yeşil alan oluşturmaktadır. Bu toplam yeşil alanın ise \% 3.63'ünü aktif yeşil alan oluşturmuştur. Bahçelievler ilçesinde genel olarak kişi başına düşen $1.91 \mathrm{~m}^{2}$ yeşil alan miktarı mevcut iken, aktif yeşil alan miktarı ise $0.89 \mathrm{~m}^{2 \prime}$ dir.

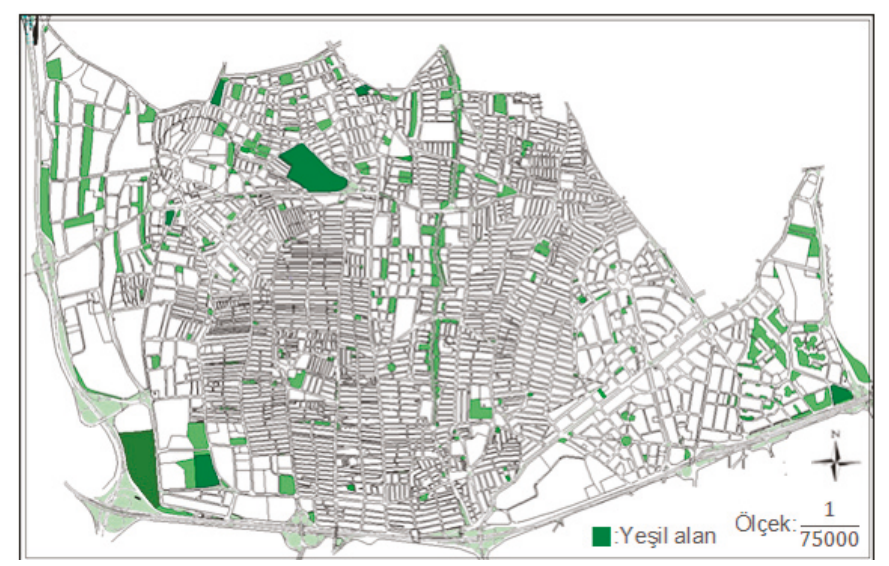

Şekil 3. Bahçelievler ilçesi planlama sınırı içindeki yeşil alanlar. Figure 1. Location map of Bahçelievler district.

\section{2. Çalışmanın Nicel Bulguları}

Ankete katılanların yaş grupları incelendiğinde çoğunlukla orta yaş grubundan oluşmaktadır. \% 19,2'si 0 ile 19 yaş arasında ( $n=91), \% 46,3^{\prime}$ ü 20 ile 39 yaş arasında ( $\left.n=219\right), \%$ 26,2'si 40 ile 59 yaş arasında ( $n=124), \% 8,2$ 'si 60 yaş ve üzeridir( $n=39)$. Katilımcıların eğitim düzeylerine göre değişimi ise şu şekildedir;
\% 0,2'sinin okuma yazması yok ( $n=1), \% 34,5^{\prime}$ i ilköğretim mezunu ( $n=163$ ), \% 34,5'i ortaöğretim mezunu ( $n=163$ ), \% 30,9'u üniversite mezunudur ( $n=146)$. Katılımcıların \% 61,3'ü evli iken ( $n=290), \% 38,7$ 'si bekârdır ( $n=183)$. Katılımcıların sahip oldukları çocuk sayıları şu şekildedir; \% 26,9'unun 1 çocuğu ( $n=79)$, $\% 42,2^{\prime} \operatorname{sinin} 2$ çocuğu ( $\left.n=124\right), \% 18,7$ 'sinin 3 çocuğu ( $\left.n=55\right)$ ve 12,2 'sinin 4 ve daha fazla çocuğu vardır. Katılımcıların mesleklere göre dağılımı şu şekildedir; \% 19,7'si ev hanımı (n=93), \% $19,7$ 'si işçi ( $n=93), \% 14,2$ 'si memur ( $n=67), \% 7,4^{\prime}$ ü emekli $(n=35), \% 15,6^{\prime}$ sı serbest meslek $(n=74), \% 23,5^{\prime} i$ ise diğer ( $n=111)$ meslek gruplarına sahiptir. Katlımcıların \% 69,8'i Bahçelievler'de ikamet ederken ( $n=330$ ), \% 27,9'u İstanbul'da başka bir ilçede ( $n=132), \%$ 2,3'ü ise İstanbul dışında ikamet etmektedirler( $n=11)$. Katılımcıların \% 58,4'ü ev sahibi iken ( $n=276), \%$ 41,6'sı kiracıdır ( $n=197$ ). Katılımcıların gelirlerine göre değişimi ise şu şekildedir; \% 34,5'i 1000 TL alt (n=163), \% 31,7'si 1001 TL ile 2000 TL arası ( $n=150), \%$ 29,6'sı 2001 ile 5000 TL arası ( $n=140), \%$ 4,2'si ise 5000 TL ve üzeri gelire sahiptir ( $n=20)$.

Park kullanımına dair istatistikler: Katlımcıların park kullanıma dair sorulara verdikleri cevapların frekans dağılımı (n) ve yüzdeleri Tablo 3'te sunulmuştur.

Tablo 4. Park kullanıma dair istatistikler (serbest zaman ve parkları kullanma sebebi).

Table 4. Statistics on parking usage.

\begin{tabular}{|llrc|}
\hline & & Frekans (n) & Yüzde (\%) \\
\hline Serbest zamanlarınıı en çok & Kent parklarında & 291 & 61,5 \\
nerede geçirirsiniz? & AVM, kafe gibi kapalı mekânlarda & 63 & 13,3 \\
& Orman içi alanlarda & 10 & 2,1 \\
& Evde & 87 & 18,4 \\
& Diğer & 22 & 4,7 \\
\cline { 2 - 4 } & Toplam & 473 & 100,0 \\
\hline Parkları kullanma sebebiniz nedir? & Hava almak-dinlenmek & 161 & 34,0 \\
& Çocukları gezdirmek-oynatmak & 215 & 45,5 \\
& Spor yapmak & 30 & 6,3 \\
& Yürüyüș-gezinti yapmak & 52 & 11,0 \\
& Piknik yapmak & 15 & 3,2 \\
\cline { 2 - 4 } & Toplam & 473 & 100,0 \\
\hline
\end{tabular}

Katılımcıların "Serbest zamanlarınızı en çok nerede geçirirsiniz?" sorusuna verdikleri cevapların dağılımları şu şekildedir; \% 61,5'i kent parklarında, \% 13,3'ü AVM, kafe gibi kapalı mekânlarda, \% 2,1'i orman içi alanlarda, \% 18,4'ü evde, \% 4,7'si ise diğer alanlarda geçirmektedir. "Parkları kullanma sebebiniz nedir?" sorusunda verilen cevaplar şu şekildedir; \% 34'ü hava almak-dinlenmek, \% 45,5'i çocukları gezdirmek-oynatmak, \% 6,3'ü spor yapmak, \% 11'i yürüyüş gezinti yapmak, \% 3,2'si piknik yapmayı tercih etmektedir.

Park kullanım alışkanlıkları arasındaki farklar: Araştırmanın bu kısmında katılımcılara parkları kullanma alışkanlıkları ile ilgili sorulan sorulara verilen yanıtlar bakımından bazı demografik gruplar arasındaki farklar irdelenecektir. Kontrol değişkeni ve araştırma değişkeni kategorize değişkenler olan bu irdelenme sırasında Ki-Kare testinden faydalanılacaktır.

Cinsiyete göre park kullanım alışkanlıkları arasındaki farklar: Kadın ve erkek katılımcıların park kullanım alışkanlıkları ile ilgili sorulara verdikleri cevapların dağılımları ile farkların anlamlıIıklarının sınanması amacıyla yapılan Ki-Kare Test istatistikleri ve anlamlılık değerlerine göre "Serbest zamanlarınızı en çok nerede geçirirsiniz?" sorusuna verilen cevaplar bakımından kadın ve erkek katılımcılar arasında istatistiksel olarak anlamlı 
bir farkın bulunmadığı görülmüştür $(p>0,05)$.

Tablo 5. Park kullanıma dair istatistikler (parkta kalış süresi ve kiminle geldiği). Table 5. Statistics on parking usage (spare time and reason for using parks).

\begin{tabular}{|lrrc|}
\hline & Frekans (n) & Yüzde (\%) \\
\hline Parkta kalşs süreniz ortalama ne kadar? 1 saatten az & 75 & 15,9 \\
& $1-2$ saat & 292 & 61,7 \\
& $3-4$ saat & 75 & 15,9 \\
& $5-6$ saat & 25 & 5,3 \\
& Tüm gün & 6 & 1,3 \\
\cline { 2 - 4 } & Toplam & 473 & 100,0 \\
\hline Parka kiminle geldiniz? & Tek & 83 & 17,5 \\
& Arkadaş grubu & 128 & 27,1 \\
& Aile ve çocuklar ile beraber & 262 & 55,4 \\
\cline { 2 - 4 } & Toplam & 473 & 100,0 \\
\hline
\end{tabular}

Kadın ve erkek katılımcıların "Parkları kullanma sebebiniz nedir?" sorusuna verdikleri cevaplar bakımından istatistiksel olarak anlamlı bir fark vardır ( $p<0,05)$. Kadınların \% 27,2'si parklara hava almak, dinlenmek amacıyla giderken erkek katılımcıların \% 37,8'i parklara bu sebeple gitmektedir. Kadınların \% $56,8^{\prime}$ i parklara çocuklarını gezdirmek, oynatmak amacıyla giderken erkeklerde bu amaç ile parka gitme oranı \% 39,1'dir. Kadınların spor yapmak amacıyla parka gitme yüzdesi \% 3,6 iken erkeklerde bu oran \% 7,9'dur. Kadınların \% 11,2'si parklara yürüyüş ve gezinti yapmak amacıyla giderken, erkeklerde bu oran \% 10,9'dur. Katilımcı kadınların \% 1,2'si parklara piknik yapmak amacıyla giderken, erkeklerde bu oran \% 4,3'dür.

Kadın ve erkek katılımcılar arasında "Bu parka ortalama ne kadar sürede geliyorsunuz?" sorusuna verdikleri yanıtlar bakımından istatistiksel olarak anlamlı bir fark yoktur $(p>0,05)$ sonucuna ulaşılmıştır.

Tablo 6. Cinsiyete göre park kullanım alışkanlıkları ki-kare test istatistikleri. Table 6. Park usage habits by gender chi-square test statistics.

\begin{tabular}{|c|c|c|c|c|c|c|c|c|}
\hline & & & \multirow[b]{2}{*}{$\mathrm{n}$} & Kadın & \multicolumn{2}{|c|}{ Erkek } & \multirow{2}{*}{$\begin{array}{l}\text { Ki- } \\
\text { Kare }\end{array}$} & \multirow[b]{2}{*}{$\mathrm{p}$} \\
\hline & & & & $\%$ & n & $\%$ & & \\
\hline \multirow{9}{*}{$\begin{array}{l}\text { Bu parkı tercih } \\
\text { etmenizin sebebi } \\
\text { nedir? }\end{array}$} & Yakın olduğu için & 116 & & 68,6 & 219 & 72,0 & \multirow{9}{*}{14,946} & \multirow{9}{*}{, $005 *$} \\
\hline & Restoran, kafe, büfe gibi & 0 & & 0,0 & & 1,6 & & \\
\hline & mekânlar olduğu için & & & & & & & \\
\hline & Çocuk oyun alanları olduğu & 39 & & 23,1 & \multirow{2}{*}{37} & \multirow[t]{2}{*}{12,2} & & \\
\hline & için & & & & & & & \\
\hline & Kalabalık olmadığı için & 12 & & 7,1 & 31 & 10,2 & & \\
\hline & Futbol, basketbol, voleybol & 2 & & 1,2 & & 3,9 & & \\
\hline & sahalarmdan biri olduğu & & & & 12 & & & \\
\hline & için & & & & & & & \\
\hline \multirow{5}{*}{$\begin{array}{l}\text { Parka gelis yolunuz } \\
\text { hangisidir? }\end{array}$} & Yürüyerek & 152 & & 89,9 & 243 & 79,9 & \multirow{5}{*}{11,888} & \multirow{5}{*}{0580} \\
\hline & Otobüs & 2 & & 1,2 & 14 & 4,6 & & \\
\hline & Özel araba & 12 & & 7,1 & 44 & 14,5 & & \\
\hline & Bisiklet & 0 & & 0,0 & 0 & 0,0 & & \\
\hline & Metro & 3 & & 1,8 & 2 & 0,7 & & \\
\hline \multirow{5}{*}{$\begin{array}{l}\text { Parka en çok hangi } \\
\text { mevsimde } \\
\text { geliyorsunuz? }\end{array}$} & İlkbahar & 28 & & 16,6 & 45 & 14,8 & \multirow{5}{*}{14,646} & \multirow{5}{*}{065} \\
\hline & Yaz & 72 & & 42,6 & 140 & 46,1 & & \\
\hline & Sonbahar & 0 & & $0,0 \%$ & 0 & 0,0 & & \\
\hline & Kış & 1 & & 0,6 & 1 & 0,3 & & \\
\hline & Mevsim șartı aranmaksızın & 68 & & 40.2 & 118 & 38.8 & & \\
\hline
\end{tabular}

Kadın ve erkek katılımcılar arasında "Bu parkı tercih etmenizin sebebi nedir?" sorusuna verdikleri yanıtlar bakımından istatistiksel olarak anlamlı bir fark mevcuttur. Kadınların \% 68,6'sı yakın olduğu için cevabını verirken, erkeklerde bu oran \% 72 'dir. Erkeklerin \% 1,6'sı restoran, kafe, büfe gibi mekânlar olduğu için cevabını verirken, kadınlardan bu cevaba katılan olmamıştrr. Kadınların \% 23,1'i çocuk oyun alanları olduğu için parka geldiğini ifade ederken, erkeklerde bu oran \% 12,2'dir. Kadınların \% 7,1'i parka kalabalık olmadı̆̆ı için geldiğini ifade ederken erkeklerde bu oran \% 10,2'dir. Kadınların \% 1,2'si parka futbol, basketbol, voleybol sahalarından biri olduğu için geldiğini ifade ederken erkeklerde bu oran \% 3,9'dur.

Kadın ve erkek katılımcılar arasında "Parka geliş yolunuz hangisidir?", "Parka en çok hangi mevsimde geliyorsunuz?" sorularına verilen yanıtlar bakımından istatistiksel olarak anlamlı bir fark yoktur.

Tablo 7. Cinsiyete göre park kullanım alışkanlıkları ki-kare test istatistikleri. Table 7. Park use habits by gender as chi-square test statistics.

\begin{tabular}{|c|c|c|c|c|c|c|c|}
\hline & & \multicolumn{3}{|c|}{ Kadın } & \multicolumn{2}{|c|}{ Erkek } & \multirow[b]{2}{*}{ p } \\
\hline & & $\mathbf{n}$ & $\%$ & $\mathrm{n}$ & $\%$ & Ki-Kare & \\
\hline \multirow[t]{5}{*}{ Parka ne ssklikla geliyorsunuz? } & Haftada $1 \mathrm{kez}$ & 28 & 16,6 & 82 & 27,0 & & \\
\hline & Haftada 2-3 kez & 51 & 30,2 & 99 & 32,6 & & \\
\hline & Haftada 3 'ten fazla & 62 & 36,7 & 75 & 24,7 & 4,092 &, 394 \\
\hline & Ayda 1 kez & 21 & 12,4 & 25 & 8,2 & & \\
\hline & Yılda buikaç kez & 7 & 4,1 & 23 & 7,6 & & \\
\hline \multirow{5}{*}{$\begin{array}{l}\text { Parkı en çok hangi saatler } \\
\text { arasında ziyaret ediyorsunuz? }\end{array}$} & $06.00-09.00$ & 0 & 0,0 & 2 &, 7 & & \\
\hline & $09.00-12.00$ & 12 & 7,1 & 20 & 6,6 & & \\
\hline & $13.00-16.00$ & 123 & 72,8 & 208 & 68,4 & 8,931 & ,063 \\
\hline & $17.00-20.00$ & 34 & 20,1 & 70 & 23,0 & & \\
\hline & $21.00-24.00$ & 0 & 0,0 & 4 & 1,3 & & \\
\hline \multirow{5}{*}{$\begin{array}{l}\text { Parkta kalış süreniz ortalama ne } \\
\text { kadar? }\end{array}$} & 1 saatten az & 24 & 14,2 & 51 & 16,8 & & \\
\hline & $1-2$ saat & 114 & 67,5 & 178 & 58,6 & & \\
\hline & 3-4 saat & 27 & 16,0 & 48 & 15,8 & 34,879 & , $000^{\circ}$ \\
\hline & $5-6$ saat & 3 & 1,8 & 22 & 7,2 & & \\
\hline & Tüm gün & 1 & 6 & 5 & 1,6 & & \\
\hline
\end{tabular}

Kadın ve erkek katılımcılar arasında "Parka ne sıklıkla geliyorsunuz?", "Parkı en çok hangi saatler arasında ziyaret ediyorsunuz", sorularına verilen yanıtlar bakımından istatistiksel olarak anlamlı bir fark yoktur.

Tablo 8. Cinsiyete göre park kullanım alışkanlıkları ki-kare test istatistikleri. Table 8. Park use habits by gender as chi-square test statistics.

\begin{tabular}{|c|c|c|c|c|c|c|c|}
\hline & & \multicolumn{2}{|c|}{ Kadin } & \multicolumn{2}{|c|}{ Erkek } & & \multirow[b]{2}{*}{$\mathrm{p}$} \\
\hline & & $\mathbf{n}$ & $\%$ & $\mathbf{n}$ & $\%$ & Kl-Kare & \\
\hline \multirow[t]{3}{*}{ Parka kiminle geldiniz? } & Tek & 11 & 6,5 & 72 & 23,7 & \multirow{3}{*}{21,929} & \multirow{3}{*}{, 110} \\
\hline & Arkadaș grubu & 36 & 21,3 & 92 & 30,3 & & \\
\hline & Aile ve çocuklar ile beraber & 122 & 72,2 & 140 & 46,1 & & \\
\hline Bahçelievler ilçesindeki & Zübeyde Hanım Park1 & 11 & 6,5 & 16 & 5,3 & \multirow{16}{*}{32,490} & \multirow{16}{*}{.520} \\
\hline rekreasyon(piknik ve eğlence) & Milli Egemenlik Park1 & 21 & 12,4 & 23 & 7,6 & & \\
\hline alanlarından en çok hangisini tercih & Şehir Korusu & 5 & 3,0 & 23 & 7,6 & & \\
\hline \multirow[t]{13}{*}{ etmektesiniz? } & Yıldrrm Beyazıt Parkı & 8 & 4,7 & 20 & 6,6 & & \\
\hline & Siyavușpaşa Parkı & 13 & 7,7 & 18 & 5,9 & & \\
\hline & Orhan Gazi Park1 & 8 & 4,7 & 15 & 4,9 & & \\
\hline & Şehit İbrahim Koparır Parkı & 12 & 7,1 & 17 & 5,6 & & \\
\hline & Şelale Sağlıklı Yaşam Park1 & 9 & 5,3 & 17 & 5,6 & & \\
\hline & Paşa Sokak Park1 & 14 & 8,3 & 14 & 4,6 & & \\
\hline & Yeni Șehir Korusu & 7 & 4,1 & 18 & 5,9 & & \\
\hline & Aliya İzzet Begoviç Parkı & 8 & 4,7 & 10 & 3,3 & & \\
\hline & Cumhuriyet Parkı & 5 & 3,0 & 19 & 6,3 & & \\
\hline & Kuleli Parkı & 9 & 5,3 & 19 & 6,3 & & \\
\hline & Doğan Koloğlu Parkı & 8 & 4,7 & 19 & 6,3 & & \\
\hline & Sezer Gezer Sokak Park1 & 15 & 8,9 & 12 & 3,9 & & \\
\hline & Diğer... & 16 & 9,5 & 44 & 14,5 & & \\
\hline
\end{tabular}

Kadın ve erkek katılımcıların parkta kalış sürelerine dair verdikleri cevaplar arasında istatistiksel olarak anlamlı farklılıklar var$\operatorname{dır}(p<0,05)$. Kadınların \% 14,2'si parkta ortalama 1 saatten az kalırken, erkeklerde bu oran \% 16,8'dir. Kadınların \% 67,5'i 
parka 1 ile 2 saat arasında ortalama süre geçirirken, erkeklerde bu oran $\% 58,6$ 'dır. Kadınların \% 16'sı parkta 3 ile 4 saat arasında kalırken erkeklerde bu oran \% 15,8'dir. Kadınların \% 1,8'i parkta 5 ile 6 saat arasında kalırken erkeklerde bu oran \% 7,2'dir. Kadınların \% 0,6'sı parkta tüm gün kalırken, parkta tüm gün kalan erkeklerin oranı \% 1,6'dır.

Kadın ve erkek katılımcılar arasında "Parka kiminle geldiniz?" ve "Bahçelievler ilçesindeki rekreasyon (piknik ve eğlence) alanlarından en çok hangisini tercih etmektesiniz?" sorularına verilen yanıtlar bakımından istatistiksel olarak anlamlı bir fark yoktur.

Yaş gruplarına göre park kullanım alışkanlıkları arasındaki farklar: Farklı yaş aralıklarındaki katılımcıların park kullanım alışkanlıkları ile ilgili sorulara verdikleri cevapların dağılımları ile farkların anlamlılıklarının sınanması amacıyla yapılan Ki-Kare Test istatistikleri ve anlamlılık değerleri Tablo 8'de verilmiştir.

Tablo 9. Yaş gruplarına göre park kullanım alışkanlıkları ki-kare test istatistikleri.

Table 9. Park usage habits by age groups chi-square test statistics.

\begin{tabular}{|c|c|c|c|c|c|c|c|c|c|c|c|}
\hline & & \multicolumn{2}{|c|}{$0-19$ yas } & \multicolumn{2}{|c|}{ 20-39 yas } & \multicolumn{2}{|c|}{$40-59$ yas } & \multicolumn{2}{|c|}{$60+$ yas } & \multirow[b]{2}{*}{ Ki-Kare } & \multirow[b]{2}{*}{$\mathrm{p}$} \\
\hline & & $\mathbf{n}$ & $\%$ & $\mathrm{n}$ & $\%$ & $\mathrm{n}$ & $\%$ & $\mathbf{n}$ & $\%$ & & \\
\hline Serbest zamanlarınız & Kent parklarnda & 42 & 46,2 & 130 & 59,4 & 87 & 70,2 & 32 & 82,1 & \multirow{7}{*}{32,51} & \multirow{7}{*}{, $001^{*}$} \\
\hline en çok nerede & AVM, kafc gibi & 22 & 24,2 & 31 & 14,2 & & 6,5 & 2 & 5,1 & & \\
\hline \multirow[t]{5}{*}{ geçirirsiniz? } & kapalı mekânlarda & & & & & 8 & & & & & \\
\hline & Orman $\quad$ içi & 5 & 5,5 & 4 & 1,8 & & 8 & 0 & 0,0 & & \\
\hline & & & & & & 1 & & & & & \\
\hline & Evde & 17 & 18,7 & 45 & 20,5 & 22 & 17,7 & 3 & 7,7 & & \\
\hline & Diğer & 5 & 5,5 & 9 & 4,1 & 6 & 4,8 & 2 & 5,1 & & \\
\hline \multirow[t]{5}{*}{$\begin{array}{l}\text { Parklan kullanma } \\
\text { sebebiniz nedir? }\end{array}$} & $\begin{array}{l}\text { Hava almak- } \\
\text { dimlenmek }\end{array}$ & 43 & 47,3 & 60 & 27,4 & 41 & 33,1 & 17 & 43,6 & \multirow{5}{*}{47,974} & \multirow{5}{*}{, $000^{*}$} \\
\hline & $\begin{array}{l}\text { Çocukları } \\
\text { gezdirmek- }\end{array}$ & 3 & 3,3 & 131 & 59,8 & 67 & 54,0 & 14 & 35,9 & & \\
\hline & oynatmak & 20 & 200 & 4 & 18 & 3 & 24 & 3 & 77 & & \\
\hline & $\begin{array}{l}\text { Yuruyuss-gezinti } \\
\text { yapmak }\end{array}$ & 14 & 15,4 & 23 & 10,5 & 11 & 8,9 & 4 & 10,3 & & \\
\hline & Piknik yapmak & 11 & 12,1 & 1 & .5 & 2 & 1,6 & 1 & 2,6 & & \\
\hline Bu parka ortalama ne & $5 \mathrm{dk}$. & 24 & 26,4 & 79 & 36,1 & 56 & 45,2 & 23 & 59,0 & \multirow{5}{*}{82,83} & \multirow{5}{*}{, $000 *$} \\
\hline kadar surede & $10 \mathrm{dk}$. & 25 & 27,5 & 91 & 41,6 & 53 & 42,7 & 13 & 33,3 & & \\
\hline \multirow[t]{3}{*}{ geliyorsunuz? } & $30 \mathrm{dk}$ & 31 & 34,1 & 33 & 15,1 & 11 & 8,9 & 3 & 7,7 & & \\
\hline & $60 \mathrm{dk}$. & 7 & 7,7 & 9 & 4,1 & 4 & 3,2 & 0 & 0,0 & & \\
\hline & 1,5-5 saat & 4 & 4,4 & 7 & 3,2 & 0 & 0,0 & 0 & 0,0 & & \\
\hline
\end{tabular}

Medeni duruma göre park kullanım alışkanlıkları arasındaki farklar: Evli ve bekâr katılımcıların park kullanım alışkanlıkları ile ilgili sorulara verdikleri cevapların dağılımları ile farkların anlamlılıklarının sınanması amacıyla yapılan Ki-Kare Test istatistikleri ve anlamlılık değerleri Tablo 9'da sunulmuştur.

Tablo 10. Medeni duruma göre park kullanım alışkanlıkları ki-kare test istatistikleri.

Table 10. Park use habits by marital status as chi-square test statistics.

\begin{tabular}{|c|c|c|c|c|c|c|c|}
\hline & & \multicolumn{2}{|c|}{ Evli } & \multicolumn{2}{|c|}{ Bekâr } & \multirow{2}{*}{$\begin{array}{c}\text { Ki- } \\
\text { Kare }\end{array}$} & \multirow[b]{2}{*}{$\mathbf{p}$} \\
\hline & & n & $\%$ & n & $\%$ & & \\
\hline Serbest zamanlarmizı en & Kent parklarinda & 201 & $69,3 \%$ & 90 & 49,2 & \multirow{5}{*}{35,130} & \multirow{5}{*}{, $000^{*}$} \\
\hline \multirow[t]{4}{*}{ çok nerede geçirirsiniz? } & $\triangle \mathrm{VM}$, kafe gibi kapalı & 19 & $6,6 \%$ & 44 & 24,0 & & \\
\hline & Orman içi alanlarda & 4 & $1,4 \%$ & 6 & 3,3 & & \\
\hline & Fvde & 53 & $18,3 \%$ & 34 & 18,6 & & \\
\hline & Diğer & 13 & $4,5 \%$ & 9 & 4,9 & & \\
\hline kullanma & Hava almak-dinlenmek & 65 & $22,4 \%$ & 96 & 52,5 & \multirow{6}{*}{$\begin{array}{c}175,00 \\
3\end{array}$} & \multirow{6}{*}{, $000^{*}$} \\
\hline \multirow[t]{5}{*}{ sebebiniz nedir? } & Çocukları $\quad$ gezdirmek- & 200 & $69,0 \%$ & 15 & 8,2 & & \\
\hline & oynatmak & & & & & & \\
\hline & Spor yapmak & 6 & $2,1 \%$ & 24 & 13,1 & & \\
\hline & Yưrlyytşs-gezinti yapmak & 17 & $5,9 \%$ & 35 & 19,1 & & \\
\hline & Piknik yapmak & 2 &, $7 \%$ & 13 & 7,1 & & \\
\hline Bu parka ortalama ne & $5 \mathrm{dk}$ & 131 & $45,2 \%$ & 51 & 27,9 & \multirow{5}{*}{42,790} & \multirow{5}{*}{, $000^{*}$} \\
\hline \multirow[t]{4}{*}{ kadar sürede gcliyorsunuz? } & $10 \mathrm{dk}$. & 119 & $41,0 \%$ & 63 & 34,4 & & \\
\hline & $30 \mathrm{dk}$ & 33 & $11,4 \%$ & 45 & 24,6 & & \\
\hline & $60 \mathrm{dk}$ & 6 & $2,1 \%$ & 14 & 7,7 & & \\
\hline & $1,5-2$ saat & 1 &, $3 \%$ & 10 & 5,5 & & \\
\hline
\end{tabular}

Evli ve bekâr katılımcılar arasında "Serbest zamanlarınızı en çok nerede geçirirsiniz ?" sorusuna verdikleri cevaplar bakımında \% 95 güven düzeyinde istatistiksel olarak anlamlı farklılıklar vardır $(p<0,05)$. Evli katilımcıların \% 69,3'ü kent parklarında, \% 6,6'sı AVM, kafe gibi kapalı mekânlarda, \% 1,4'ü orman içi alanlarda, \% 18,3'ü ise evde, \% 4,5'i diğer cevabını verirken, bekâr katılımcıların \% 49,2'si kent parklarında, \% 24'ü AVM, kafe gibi kapalı mekanlarda, \% 3,3'ü orman içi alanlarda, $\% 18,6$ 'sı ise evde, \% 4,9'u diğer cevabını vermiştir.

Katılımcıların medeni durumlarına göre " Parkları kullanma sebebiniz nedir?" sorusuna verdikleri cevaplar bakımından \% 95 güven düzeyinde istatistiksel olarak anlamlı farklılığa sahiptir $(p<0,05)$. Evli katılımcıların bu soruya verdikleri cevaplar şu şekildedir; \% 22,4'ü hava almak, dinlenmek, \% 69'u çocukları gezdirmek, oynatmak, \% 2,1'i spor yapmak, \% 5,9'u yürüyüş, gezinti yapmak, \% 0,7'si piknik yapmaktadır. Bu durum çocukların gelişim sürecinde parkların ne kadar önemli olduğunu ortaya koymaktadır. Bekâr katılımcıların ise bu soruya verdikleri yanıtlar şu şekildedir; \% 52,5'i hava almak, dinlenmek, \% 8,2'si çocukları gezdirmek, oynatmak, \% 13,1'i spor yapmak, \% 19,1'i yürüyüş, gezinti yapmak, \% 7,1'i piknik yapmaktadır.

Evli ve bekâr katılımcılar arasında "Bu parka ortalama ne kadar sürede geliyorsunuz?" sorusuna verdikleri yanıtlar bakımından \% 95 güven düzeyinde istatistiksel olarak anlamlı farklılıklar saptanmıştır $(p<0,05)$. Evli katılımcıların bu soruya verdikleri cevap yüzdeleri şu şekildedir; \% 45,2'si 5 dakika, \% 41'i 10 dakika, \% 11,4'ü 30 dakika, \% 2,1'i 60 dakika, \% 0,3'ü 1,5 ile 2 saat arasında ulaşmaktadır. Bekâr katılımcıların ise bu soruya verdikleri yanıtlara ait yüzdeler şu şekildedir; \% 27,9'u 5 dakika, \% 34,4'ü 10 dakika, \% 24,6'sı 30 dakika, \% 7,7'si 60 dakika, \% 5,5’i 1,5 ile 2 saat arasında ulaşmaktadır.

Donat alanı isteklerine dair farkındalık istatistikleri: Ankete katılan 473 kişi ile aynı zamanda mülakat yapılmış ve mülakatta sorulan 2 soruya aşağıda yer verilmiştir. Ayrıca arazi çalışmasında elde edilen verilere (tuvalet, güvenlik kamerası, güvenlik personeli, basketbol veya futbol alanı) Tablo 10 'da verilmiştir.

Tablo 11. Donatı alanı isteklerine dair farkındalık istatistikleri. Table 11. Awareness statistics on reinforcement area requests.

\begin{tabular}{|llc|}
\hline & Evet & Hayır \\
Parktaki yol işareti ve yönlendirici levhalar yeterli & $\% 9,7$ & $\% 90,3$ \\
mi? & & \\
Parktaki çöp kutularını yeterli görrïyor musunuz? & $\% 67,9$ & $\% 32,1$ \\
Parkta tuvalet var mı? & $\% 46,6(7$ park $)$ & \\
Parkta güvenlik kamerası var mı? & $\% 26,6(4$ park $)$ & \\
Parkta güvenlik personeli var mı? & $\% 20(3$ park $)$ & \\
Parkta basketbol veya futbol alanlarından herhangi & $\% 46,6(7$ park $)$ \\
biri var mı? & & \\
\hline
\end{tabular}

Katılımcılar ile yapılan mülakata katılanların \% 9,7'si parktaki yol işaretleri ve yönlendirici levhaları yeterli bulurken $(n=46)$, $\% 90,3^{\prime} u ̈$ yetersiz bulmaktadır ( $\left.n=427\right)$. Katlımcıların \% $67,9$ 'una göre parktaki çöp kutuları yeterli görülürken ( $n=321)$, \% 32,1'ine göre yetersizdir ( $n=152)$.

Araştırma alanı içerisinde bulunan 15 parka yönelik yapılan alan gözlem çalışması sonucunda; parkların \% 46,6 (7 park)'sında tuvalet, \% 26,6 (4 park)'sında güvenlik kamerası, \% 20 (3 park)'sinde güvenlik personeli, \% 46,6 (7 park )'sında bas- 
ketbol veya futbol alanlarından biri bulunmaktadır.

Parkların genel memnuniyet düzeyine dair istatistikler: Kathlımcıların anketin son bölümünde yer alan parkların genel memnuniyet düzeyine dair $5^{\prime}$ li Likert tipteki sorulara verdikleri cevaplara ait istatistiklere göre en yüksek 3 memnuniyet düzeyinin (orta düzeyde yeterli olduğu) "Parklar, kentin yoğun baskısından kurtulup psikolojik, fizyolojik, sosyal anlamda ihtiyaçlarınızı ne düzeyde karşılamaktadır?", "Oturma banklarını ne düzeyde yeterli buluyorsunuz?" ve "Bu park alanını(genişliğini) ne düzeyde yeterli buluyorsunuz?" soruları ile ölçümlenen memnuniyet düzeyleri olduğu, en düşük dört memnuniyet düzeyinin (kötü) ise "Kum havuzlarını ne düzeyde yeterli buluyorsunuz?", Parkın güvenliğini nasıl değerlendiriyorsunuz?", Parktaki tesisleri ne düzeyde yeterli görüyorsunuz?" ve "Parkı gece kullanımına ne derece uygun buluyorsunuz?" soruları ile ölçümlenen memnuniyet düzeyleri olduğu gözlenmiştir.

Parkların genel memnuniyet düzeyi arasındaki farklılıklar: Araştırmanın bu kısmında parkların genel memnuniyet düzeyinin demografik gruplar arasındaki farklılıkları incelenecektir. Bölümden sorulan soruların 5'li likert tipte olması sebebiyle söz konusu bölümde iki gruba ait demografik değişkenler olan cinsiyet ve medeni durum değişkeni ile yapılacak farklılık analizlerinde Mann- Whitney U Testi, ikiden fazla gruba sahip yaş grupları demografik değişkeni ile yapılacak farklılık analizlerinde ise Kruskal Wallis $\mathrm{H}$ Testi uygulanmıştır. Kruskal Wallis $\mathrm{H}$ Testi sonucu aralarında istatistiksel farklar bulunan sorular için farkın kaynağı olan grupların tespiti amacıyla gruplar arasında ikili Mann- Whitney U Testleri yapılmıştır.

Cinsiyete göre parka dair görüşlerdeki farklılıklar: Gidilen park türüne yönelik $5^{\prime}$ li likert tipte hazırlanmış sorulara verilen cevaplar bakımından kadın ve erkek katılımcılar arasındaki farkların sınanabilmesi amacıyla yapılan Mann- Whitney U Testi istatistikleri Tablo 11'deki gibidir.

"Parktaki spor aletlerini ne düzeyde yeterli ve güvenli buluyorsunuz?" önermesine katılım dereceleri bakımından kadın ve erkek katilımcılar arasında \% 95 güven düzeyinde istatistiksel olarak anlamlı bir farkın bulunduğu gözlemlenir $(p<0,05)$. Ortalama sıralar incelendiğinde kadın katlımcıların ortalama sıraları daha yüksek olduğu görülür. Daha açık bir ifade ile kadın katılımcılara göre parktaki spor aletleri daha yeterli ve güvenlidir. \% 95 güven düzeyinde kadın ve erkek katılımcılar arasında bir diğer fark ise "Çocuk oyun aletlerini ne derece yeterli buluyorsunuz?" önermesine katılım durumunda ortaya çıkmaktadır $(p<0,05)$. Ortalama sıralar incelendiğinde erkek katılımcıların daha yüksek ortalama sıra değerlerine sahip olduğu gözlemlenir. Daha açık bir ifade ile erkek katılımcılara göre parktaki çocuk oyun aletleri daha yeterlidir. Diğer önermeler için yapılan Mann Whitney U Testi anlamlılık değerleri 0,05'ten büyüktür. Daha açık bir ifade ile diğer önermelere katılımları kadın ve erkek katılımcılar açısından istatistiksel önemli denilebilecek bir fark yoktur.

Yaş gruplarına göre parka dair görüşlerdeki farklılıklar: Gidilen parka dair 5'li likert tipte hazırlanmış sorulara verilen cevaplar bakımından farklı yaş grubundaki katılımcılar arasındaki farkların sınanabilmesi amacıyla yapılan Kruskall Wallis $\mathrm{H}$ Testi gerçekleştirilmiştir. Farklı yaş grubundaki katılımcıların parklardan duydukları genel mennuniyet düzeyleri arasındaki farkların tespiti için yapılan Kruskal Wallis $\mathrm{H}$ Test istatistikleri anlamlılık de-
Tablo 12. Cinsiyete göre gidilen parka dair görüşlere ait farklar Mann-Whitney $U$ test istatistikleri

Table 12. Mann-Whitney $U$ test statistics about differences between views of the park according to gender.

\begin{tabular}{|c|c|c|c|c|c|}
\hline Değișken & Cinsiyet & $\mathbf{N}$ & $\begin{array}{c}\text { Ortalama } \\
\text { Sira }\end{array}$ & $\mathrm{z}$ & p \\
\hline \multirow{3}{*}{$\begin{array}{l}\text { Parktaki spor aletlerini ne düzeyde yeterli } \\
\text { ve güvenli buluyorsunuz? }\end{array}$} & Kadın & 169 & 254,01 & & \\
\hline & Erkek & 304 & 227,54 & $-2,115$ & ,034* \\
\hline & Toplam & 473 & & & \\
\hline \multirow{3}{*}{$\begin{array}{l}\text { Parklar, kentin yoğun baskısından kurtulup } \\
\text { psikolojik, fizyolojik, sosyal anlamda } \\
\text { ihtiyaçlarınızı ne düzeyde karşılamaktadır? }\end{array}$} & Kadin & 169 & 223,10 & & \\
\hline & Erkek & 304 & 244,73 & $-1,796$ & ,072 \\
\hline & Toplam & 473 & & & \\
\hline \multirow{4}{*}{$\begin{array}{l}\text { Parkları, ögrencilerin doğayı } \\
\text { sorgulayabildıklerı, araștırma, inceleme, } \\
\text { gezi, gözlem yapabildikleri alan olarak } \\
\text { baktığınızda ne derece katkı } \\
\text { sağlamaktadır? }\end{array}$} & Kadın & 169 & 234,55 & & \\
\hline & Erkek & 304 & 238,36 & & \\
\hline & & & & $-0,308$ &, 758 \\
\hline & Toplam & 473 & & & \\
\hline \multirow{3}{*}{$\begin{array}{l}\text { Bu park alanımı(gcnișliğini) ne düzcydc } \\
\text { yeterli buluyorsunuz? }\end{array}$} & Kadin & 169 & 235,62 & & \\
\hline & Erkek & 304 & 237,77 & $-0,173$ & ,863 \\
\hline & Toplam & 473 & & & \\
\hline \multirow{3}{*}{$\begin{array}{l}\text { Parkın ag̃açlandırma ve bitkilendirme } \\
\text { çalışmalarımı ne derece yeterli } \\
\text { görüyorsunuz? }\end{array}$} & Kadın & 169 & 231,44 & & \\
\hline & Erkek & 304 & 240,09 & $-0,700$ & ,484 \\
\hline & Toplam & 473 & & & \\
\hline \multirow{3}{*}{$\begin{array}{l}\text { Parkı, estetik (göze hoș gelen) bakımdan } \\
\text { nasıl değerlendiriyorsunuz? }\end{array}$} & Kadın & 169 & 230,81 & & \\
\hline & Erkek & 304 & 240,44 & $-0,779$ & 436 \\
\hline & Toplam & 473 & & & \\
\hline \multirow{3}{*}{$\begin{array}{l}\text { Parklaki tesisleri ne düzeyde yeterli } \\
\text { görüyorsunuz? }\end{array}$} & Kadın & 169 & 220,09 & & \\
\hline & Erkek & 304 & 246,40 & $-0,106$ &, 350 \\
\hline & Toplam & 473 & & & \\
\hline \multirow{3}{*}{$\begin{array}{l}\text { Parkın temizliğini ne düzeyde yeterli } \\
\text { görüyorsunuz? }\end{array}$} & Kadın & 169 & 232,02 & & \\
\hline & Erkek & 304 & 239,77 & $-0,626$ &, 532 \\
\hline & Toplam & 473 & & & \\
\hline \multirow{3}{*}{$\begin{array}{l}\text { Parktaki gece aydınlatmasını ne düzcyde } \\
\text { yeterli görüyorsunuz? }\end{array}$} & Kadın & 169 & 229,94 & & \\
\hline & Erkek & 304 & 240,92 & $-0,886$ &, 376 \\
\hline & Toplam & 473 & & & \\
\hline \multirow{3}{*}{$\begin{array}{l}\text { Parkın güvenliğini nasıl } \\
\text { değerlendiriyorsunuz? }\end{array}$} & Kadın & 169 & 212,89 & & \\
\hline & Erkek & 304 & 250,40 & $-0,089$ &, 252 \\
\hline & Toplam & 473 & & & \\
\hline \multirow{3}{*}{$\begin{array}{l}\text { Parka gece kullanımına ne derece uygun } \\
\text { buluyorsunuz? }\end{array}$} & Kadın & 169 & 221,15 & & \\
\hline & Erkek & 304 & 245,81 & $-1,991$ & ,056 \\
\hline & Toplam & 473 & & & \\
\hline \multirow{3}{*}{$\begin{array}{l}\text { Olurma banklarmm ne düzeyde yeterli } \\
\text { buluyorsunuz? }\end{array}$} & Kádın & 169 & 210,00 & & \\
\hline & Erkek & 304 & 252,01 & $-0,472$ &, 142 \\
\hline & Toplam & 473 & & & \\
\hline \multirow{3}{*}{$\begin{array}{l}\text { Spor alanlarımı ne derece yeterli } \\
\text { görüyorsunuz? }\end{array}$} & Kadın & 169 & 234,24 & & \\
\hline & Erkek & 304 & 238,53 & $-0,342$ &, 732 \\
\hline & Toplam & 473 & & & \\
\hline \multirow{3}{*}{$\begin{array}{l}\text { Cocuk oyun aletlerini ne derece yeterli } \\
\text { buluyorsunuz? }\end{array}$} & Kadın & 169 & 218,87 & & \\
\hline & Erkek & 304 & 247,08 & $-2,252$ & ,024* \\
\hline & Toplam & 473 & & & \\
\hline \multirow{3}{*}{$\begin{array}{l}\text { Kum havuzlarını ne düzeyde yeterli } \\
\text { buluyorsunuz? }\end{array}$} & Kadın & 169 & 225,75 & & \\
\hline & Erkek & 304 & 243,25 & $-1,555$ & , 120 \\
\hline & Toplam & 473 & & & \\
\hline
\end{tabular}

ğerleri incelendiğinde "Parklar, kentin yoğun baskısından kurtulup psikolojik, fizyolojik, sosyal anlamda ihtiyaçlarınızı ne düzeyde karşılamaktadır?" ve "Oturma banklarını ne düzeyde yeterli buluyorsunuz?" önermelerine katilımları bakımından \% 95 güven düzeyinde istatistiksel olarak anlamlı farklılıklar saptanmıştır $(p<0,05)$. Söz konusu farkların kaynağı olan grupların tespiti amacıyla, söz konusu önermeler için gruplar arası ikili karşılaştırmalar yapılmalıdır.

Farklı yaş gurubundaki katılımcılar arasında "Parklar, kentin yoğun baskısından kurtulup psikolojik, fizyolojik, sosyal anlamda ihtiyaçlarınızı ne düzeyde karşılamaktadır?" önermesine katıım bakımından ikili karşılaştırmalar amacıyla yapılan MannWhitney U Testleri Tablo 12'de derlenmiştir. 
Tablo 13. Yaş grupları Mann- Whitney U ikili karşılaştırmalar. Table 13. Mann-Whitney $U$ pair comparisons on age groups.

\begin{tabular}{|lcl|}
\hline Karşılaştırma & Ortalama Sıra Karșilaştırması & $\mathbf{p}$ \\
\hline 1.)0-19 yaș ile 2.) $20-39$ yaș & $1>2$ & $0,020^{*}$ \\
1.)0-19 yaș ile 3.) $40-59$ yaş & $1>3$ & $0,010^{*}$ \\
1.)0-19 yaș ile 4.) 60 yaş ve üzeri & $1>4$ & $0,020^{*}$ \\
2.)20-39 yaş ile 3.) $40-59$ yaș & - & 0,114 \\
2.)20-39 yaș ile 4.) 60 yaș ve üzeri & - & 0,433 \\
3.)40-59 yaş ile 4.) 60 yaş ve üzeri & - & 0,788 \\
\hline
\end{tabular}

Yapılan ikili karşılaştırmalarda anlamlı farklılığa sahip olan tüm karşılaştırmaların 0 ile 19 yaş arası katılımcılar ile diğer katılımcılar arasında olduğu gözlemlenir. Ortalama sıra karşılaştırmaları incelendiğinde ise 0 ile 19 yaş arasındaki katılımcıların diğer yaş grubundaki tüm katılımcılardan daha yüksek ortalama sıra değerlerine sahip olduğu gözlemlenir $(p<0,05)$. Daha açık bir ifade ile 0 ile 19 yaş arasındaki katılımcılara göre parklar, kentin yoğun baskısından kurtulup psikolojik, fizyolojik ve sosyal anlamda ihtiyaçları diğer katılımcılara göre daha yüksek düzeyde karşılamaktadır. Yapılan diğer ikili karşılaştırmalarda gruplar arasında \% 95 güven düzeyinde istatistiksel olarak anlamlı düzeyde bir fark bulunamamıştır ( $p>0,05)$.

Farklı yaş gurubundaki katılımcılar arasında "Oturma banklarını ne düzeyde yeterli buluyorsunuz?" sorusuna katılım bakımından ikili karşılaştırmalar amacıyla yapılan Mann- Whitney U incelendiğinde ikili karşılaştırmalarda 0 ile 19 yaş arası katılımcıları ile 40 ile 59 yaş arası katılımcılar arasında ve 0- 19 yaş ile 60 yaş ve üzeri katılımcılar içerisinde istatistiksel olarak anlamlı farklar saptanmıştır $(p<0,05)$. Ortalama sıra karşılaştırmalar incelendiğinde ise 0 ile 19 yaş arası katılımcıların ortalama sıralarının 40 ile 59 yaş ve 60 yaş ve üzeri katılımcılardan daha yüksek olduğu gözlemlenmektedir. Daha açık bir ifade ile 0 ile 19 yaş arası katılımcılara göre oturma bankları 40 ile 59 yaş arası katılımcılar ve 60 yaş ve üzeri katılımcılara göre daha yeterli düzeydedir. Yapılan diğer ikili karşılaştırmalarda istatistiksel olarak anlamlı düzeyde bir fark bulunamamıştır.

Medeni duruma göre parka dair görüşlerdeki farklılıklar: Gidilen park türüne yönelik 5'li Likert tipte hazırlanmış sorulara verilen cevaplar bakımından evli ve bekâr katılımcılar arasındaki farkların sınanabilmesi amacıyla yapılan Mann- Whitney U Testi istatistikleri ne göre "Parktaki spor aletlerini ne düzeyde yeterli ve güvenli buluyorsunuz", "Parkları, öğrencilerin doğayı sorgulayabildikleri, araştırma, inceleme, gezi, gözlem yapabildikleri alan olarak baktığınızda ne derece katkı sağlamaktadır?", "Parkın ağaçlandırma ve bitkilendirme çalışmalarını ne derece yeterli görüyorsunuz?”, "Parkı, estetik (göze hoş gelen) bakımdan nasıl değerlendiriyorsunuz?", "Parktaki tesisleri ne düzeyde yeterli görüyorsunuz?", "Parkın temizliğini ne düzeyde yeterli görüyorsunuz?”, "Parktaki gece aydınlatmasını ne düzeyde yeterli görüyorsunuz, "Parkın güvenliğini nasıl değerlendiriyorsunuz?", "Parkı gece kullanımına ne derece uygun buluyorsunuz?", "Spor alanlarını ne derece yeterli görüyorsunuz?" ve "Kum havuzlarını ne düzeyde yeterli buluyorsunuz?" önermelerine katılım bakımından evli ve bekâr katılımcılar arasında \% 95 güven düzeyinde istatistiksel bir farkın bulunmadığı görülür $(p>0,05)$.

Evli ve bekâr katılımcılar arasında "Parklar, kentin yoğun baskısından kurtulup psikolojik, fizyolojik, sosyal anlamda ihtiyaçlarınızı ne düzeyde karşılamaktadır?" önermesine katılımları bakımından \% 95 güven düzeyinde istatistiksel olarak anlamlı bir fark vardır $(p<0,05)$. Ortalama sıralar incelendiğinde bekâr katılımcıların bu önermeyi daha fazla olumladıkları gözlemlenir. Daha açık bir ifade ile bekâr katılımcılara göre parklar kentin yoğun baskısından kurtulup psikolojik, fizyolojik ve sosyal anlamda ihtiyaçlarınızı daha yüksek düzeyde karşılamaktadır.

Evli ve bekâr katılımcılar arasında "Bu park alanını (genişliğini) ne düzeyde yeterli buluyorsunuz?" önermesine katılımları bakımından \% 95 güven düzeyinde istatistiksel olarak anlamlı bir fark vardır $(p<0,05)$. Ortalama sıralar incelendiğinde bekâr katılımcıların bu önermeyi daha fazla olumladıkları gözlemlenir. Daha açık bir ifade ile bekâr katılımcılara göre parkların genişliği daha yüksek düzeyde yeterlidir.

Evli ve bekâr kathlımcılar arasında "Oturma banklarını ne düzeyde yeterli buluyorsunuz?" önermesine katılımları bakımından \% 95 güven düzeyinde istatistiksel olarak anlamlı bir fark vardır $(p<0,05)$. Ortalama sıralar incelendiğinde bekâr katılımcıların bu önermeyi evli katlımcılara göre daha fazla olumladıkları gözlemlenir. Daha açık bir ifade ile bekâr katılımcılara göre oturma bankları yeterlidir.

Evli ve bekâr kathlımcılar arasında "Çocuk oyun aletlerini ne derece yeterli buluyorsunuz?" önermesine katılımları bakımından \% 95 güven düzeyinde istatistiksel olarak anlamlı bir fark vardır $(p<0,05)$. Ortalama sıralar incelendiğinde bekâr katılımcıların bu önermeyi evli katılımcılardan daha fazla onayladıkları gözlemlenir. Daha açık bir ifade ile bekâr katılımcılara göre çocuk oyun aletleri daha yeterlidir.

Parkların Değerlendirilmesi. Anketin ölçek maddeleri arasında eleme yapılarak sadece bu parka özel ölçek sorularına yer verilmiştir. Cevapları 5'li Likert tipine uygun olarak; "1-Çok İyi, 2İyi, 3-Fena Değil, 4-Kötü, 5-Çok Kötü" olarak puanlanmıştır. Ölçek maddelerini daha iyi yorumlamak için ortalamaları aşağıdaki gibi "iyi, orta, kötü" olarak 3 bölüme ayrılmıştır.

\section{Tartışma ve Sonuç}

Bahçelievler ilçesinin toplam yüz ölçümünün sadece \% 7.79’u yeşil alan olarak ayrılmıştır. Kişi başına düşen yeşil alan durumu $1.91 \mathrm{~m}^{2}$, kişi başına düşen aktif yeşil alan ise $0.89 \mathrm{~m}^{2 \prime}$ dir. Bu durum Bahçelievler ilçesinin ülkemiz yeşil alan standardından ne kadar uzak olduğunun bir göstergesidir. Ölçülen 10 donat elemanının tamamının bulunduğu tek park Şehir Korusu'dur.
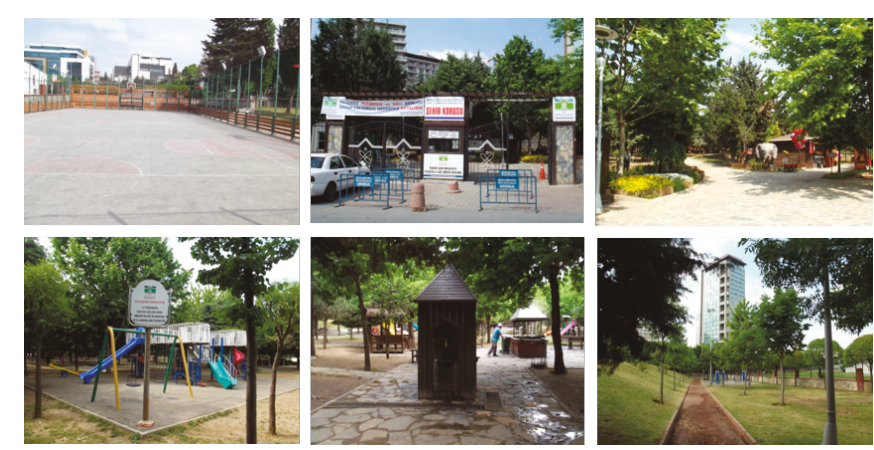

Şekil 4. Şehir Korusundan görünümler

Figure 4. Views from the City Grove.

Donatı elemanlarından sadece 2 tanesinin olmadığı parklar ise Şelale Parkı ve Yeni Şehir Korusu'dur. Donatı elemanlarından sadece 1 tanesinin olduğu park Doğan Koloğlu Parkı'dır. Donat 
elemanlarından sadece 2 tanesinin olduğu parklar ise Paşa Sokak Parkı, Sezer Gezer Sokak Parkı ve Şehit Ibrahim Koparır Parkı'dır.
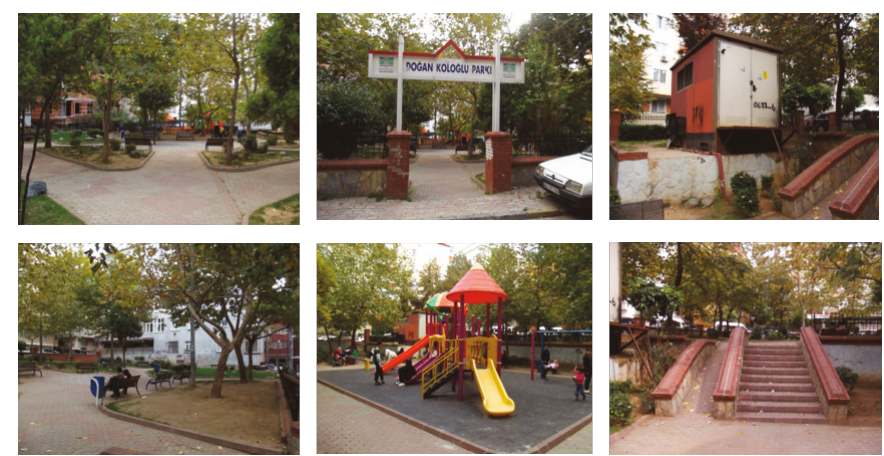

Şekil 5. Doğan Koloğlu park alanı.

Figure 5. Views from the Doğan Koloğlu Park.
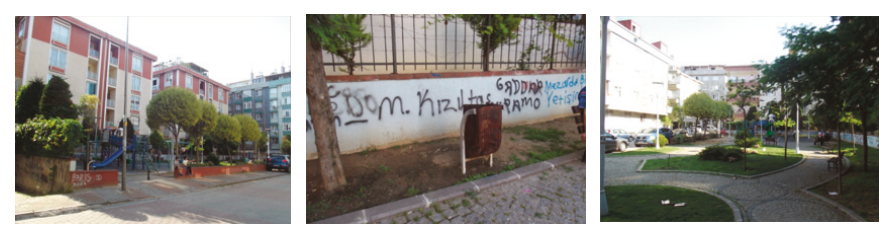

Şekil 6. Sezer Gezer Sokak Parkı

Figure 6. Views from the Sezer Gezer Street Park

Ankete katılanlar tarafindan belirlenen parkların genel memnuniyet düzeylerine ilişkin en yüksek üç maddesinde, genel olarak parkların insanların psikolojik, fizyolojik, ve sosyal anlamda intiyaçlarını büyük oranda karşıladığı, oturma banklarının ve park alanlarının orta düzeyde yeterli olduğu ölçümlenmiştir. En düşük dört memnuniyet düzeyinin (kötü) ise kum havuzları, parkın güvenliği, parktaki tesisler ve parkın gece kullanımı olduğu belirlenmiş ve yetersiz olduğu ifade edilmiştir.

WHO kişi başına düşen yeşil alan miktarını en az $9 \mathrm{~m}^{2}$ olarak belirlemiş, ülkemizde ise kişi başına düşen yeşil alan miktarı 3194 sayılı İmar Kanunu'nun 02.09.1999 tarih ve 23804 sayılı Resmi Gazete'de yayımlanan “imar Planı Yapılması ve Değişikliklerine Ait Esaslara Dair Yönetmelik" hükümlerinde $10 \mathrm{~m}^{2}$ olarak belirlenmiştir. Fakat bu ülkemizde görüldüğü üzere büyük oranda kağıt üzerinde kalmıştır. Yerel yönetimlerin bu konuda gerekli hassasiyeti göstererek kentlerdeki kişi başına düşen yeşil alan miktarını ve niteliğini artırıcı politikalar izlemelidir. Bunun için Bahçelievler'deki mevcut park alanları iyileştirilmeli ve yeni park alanları oluşturulmalıdır. Yeni park alanları tesis edilirken mevcut aktif yeşil alan bulunmayan veya az bulunan mahallelere öncelik verilmelidir. Örneğin Soğanlı, Hürriyet, Siyavuşpaşa, Cumhuriyet mahallelerinde park sayıları 1 ile 3 arasında değişmektedir. Bunu yaparken imar planında öngörülmüş küçük boşlukları park şeklinde düzenleyerek kente çok fazla sayıda park kazandırmak stratejisi yerine halkın ihtiyaçlarına cevap verebilecek standartlara uygun park alanlarının oluşturulması hedeflenmelidir.

Bahçelievler'deki park alanlarının ve çocuk oyun alanlarının mahallelere göre dağılımı homojen olmalı, imar planlarından arta kalan alanlar olarak bakılmamalıdır.

Parklardaki çocuk oyun alanlarının planlanmasında çocukların yaş gruplarına göre dağılımları göz önüne alınmalı, her yaş grubuna uygun (0-2,2-6,6-12) çocuk oyun aletleri dizayn edilmeli- dir. Çünkü her yaş grubu çocuğun oyun oynamadaki fiziksel yeterliliği farklı olduğundan meydana gelebilecek olumsuzluklara neden olmamak için bu tür ayrımın yapılması kesinlikle faydalı olacaktır. Ayrıca engelli kişilerin de istek ve ihtiyaçları dikkate alınarak tasarımlar gerçekleştirilmelidir.

Park alanlarında çok sayıda donat elemanı eksikliği bulunmaktadır. Restoran-kafe veya büfe, tuvalet, çeşme, spor aletleri, basketbol veya futbol alanı, güvenlik kamerası, güvenlik personeli, otopark, kum havuzu gibi donatı alanı elemanları eksiksiz park alanları içerisinde bulunmalıdır. Yapılacak olan yeni park alanlarının düzenlenmesinde bunların yeterli sayıda olmasına özen gösterilmelidir.

Parklardaki çöp kutularının, aydınlatma elemanlarının, oturma banklarının, kum havuzlarının, çocuk oyun aletlerinin ve spor aletlerinin bakımı ve onarımı yapılmalı; ağaçların, çimlerin ve diğer bitki örtüsünün bakımı ve sulanması düzenli olarak gerçekleştirilmelidir. Ayrıca parklardaki yol işareti ve yönlendirici levhaların yetersiz olduğu görülmektedir. Parkları ziyaret edenlerin buraları daha bilinçli kullanmaları için bu tür uyarıcı levhaların arttırılması gerekmektedir.

Park kullanıcıları, parkların temizliğini orta düzeyde yeterli olarak (ortalama 2,78) algılamışlardır. Her ne kadar kabul edilebilir olarak görülse de parkların daha sağlıklı ve yaşanabilir olması için park temizliğine gereken önem gösterilmelidir.

Park kullanıcıları, "Parklardaki gece aydınlatmasını ne düzeyde yeterli buluyorsunuz?" sorusuna orta düzeyde (ortalama 3,09) yeterli bulduklarını belirtmişlerdir. Parklardaki mevcut durumun korunarak gece aydınlatmalarının arttırılması, parkların gece kullanımının da artmasını sağlayacaktır.

Park kullanıcıları parkların güvenliğini kötü (ortalama 3,68) olarak algılamışlardır. Kullanıcıların parklarda kendilerini güvende hissetmelerine yönelik çalışmalar yapılmalıdır.

Milli Egemenlik Parkı içerisinde atıl durumda bulunan Siyavuşpaşa Çocuk Kütüphanesi'nin gerekli bakımı yapılıp aktif hale getirilerek halkın kullanımına açılması çok büyük eksikliği giderecektir.

\section{Kaynakça}

Aksoy, Y. (2004). Üsküdar ilçesi açık yeşil alan durumunun irdelenmesi. Çev-Kor Ekoloji Dergisi, 13 (52), s. 38-44.

Aksoy, Y. ve Akpınar, A. (2011). Yeşil alan kullanımı ve yeşil alan gereksinimi üzerine bir araştırma, İstanbul ili Fatih ilçesi örneği. İstanbul Ticaret Üniversitesi, Fen Bilimleri Dergisi, 20, s. 81-96.

Ayaşlıgil, T. (1998). Kent gelişimi sürecinde açık ve yeşil mekan gereksiniminin Çanakkale örneğinde irdelenmesi (Doktora tezi özeti). Istanbul Üniversitesi, Fen Bilimleri Enstitüsü, s. 39-69. Erişim http://dergipark.ulakbim.gov.tr/jffiu/article/viewFile/1023009820 /1023009113.

Bahçelievler Belediyesi Faaliyet Raporu, (2011). Bahçelievler Belediyesi Faaliyet Raporu.

Bahçelievler Belediyesi (2014). Bahçelievler Belediyesi 2015-2019 $\begin{array}{llll}\text { Stratejik Planı } & \text { s. } & 37-57 . & \text { Erişim }\end{array}$ http://www.bahcelievler.istanbul/Files/Document/yillik_faaliyet_r aporlari/2015_2019stratejik_plan.pdf, Erişim tarihi: 23 Aralık 2017

Bahçelievler Kaymakamlığı (2017). Erişim tarihi: 23 Aralık 2017, http://www.bahcelievler.gov.tr/bahcelievler-ilcesi)

Gül, A. ve Küçük, V. (2001). Kentsel açık-yeşil alanlar ve Isparta kenti örneğinde irdelenmesi. Süleyman Demirel Üniversitesi, Orman Fakültesi Dergisi, Seri: A (2), s. 27-48. 
Karasar, N. (2015). Bilimsel araştırma yöntemleri. Ankara: Nobel.

Korgavuş, B. ve Ersoy, M. (2015). Kadıköy ilçesi kentsel açık ve yeşil alanlarının olası İstanbul depreminde yeterliliğinin irdelenmesi. Uluslararası Burdur Deprem ve Çevre Sempozyumu. Burdur, Mehmet Akif Ersoy Üniversitesi.

Manavoğlu, E. ve Ortaçeşme, V. (2015). Antalya kenti yeşil alanlarının çok ölçütlü analizi ve planlama stratejilerinin geliştirilmesi. Akdeniz Üniversitesi, Ziraat Fakültesi Dergisi, 28(1), s. 11-19.

Meteoroloji Genel Müdürlüğü, (2017). Meteoroloji Genel Müdürlüğü 2016 ve öncesi verilerinden derlenmiştir.

Meteoroloji Genel Müdürlüğü, (2017). Meteoroloji Genel Müdürlüğü'nün 2017 ve öncesi Bahçelievler iklim verileri, derlenmiştir.

Özcan, K. (2006). Sürdürülebilir kentsel gelişmede açık-yeşil alanların rolü Kırıkkale, Türkiye örneği. Çev-Kor Ekoloji Dergisi, 15 (60), s. 37-45.

TÜiK, (2016). Türkiye İstatistik Kurumu'nun Bahçelievler ilçesi nüfus verileri

Yavuzçehre, P. S. ve Torlak, S. E. (2006). Kentsel yaşam kalitesi ve belediyeler: Denizli Karşıyaka Mahallesi örneği. Süleyman Demirel Üniversitesi, Sosyal Bilimler Enstitüsü Dergisi, Yıl: 2 (4).

Yenice, M.S. (2012). Kentsel yeşil alanlar için mekânsal yeterlilik ve erişebilirlik analizi; örneği, Türkiye. Süleyman Demirel Üniversitesi, Orman Fakültesi Dergisi, 13, s. 41-47.

Yılmaz, H., Yılmaz, S. ve Yıldız, N. (2003). Kars kent halkının rekreasyonel talep ve eğilimlerinin belirlenmesi. Ankara Üniversitesi, Ziraat Fakültesi Dergisi, 34(4), s. 353-360.

h tt p : / / w w w . i b b . g o v. t r / t r TR/SubSites/DepremSite/Pages/AvrupaYakasiGuneyiMikrobolgelemeProjesi.aspx, IBB-Mikrobölgeleme Projesi Avrupa Yakası, 2007, Erişim tarihi: 23 Aralık 2017 